\title{
Konflik Horisontal Antar Kelompok Korban Bencana Lumpur Lapindo
}

\author{
Oman Sukmana* \\ osukmana@ymail.com
}

\begin{abstract}
Abstrak
Fenomena yang menjadi fokus perhatian dalam penelitian ini adalah fenomena konflik yang terjadi antar kelompok korban bencana Lumpur Lapindo (Lula) di Sidoarjo. Penelitian ini bertujuan untuk mengkaji tentang: (1) Bagaimana proses terbentuknya kelompok-kelompok korban bencana Lumpur Lapindo hingga terjadinya konflik antar kelompok korban bencana Lumpur Lapindo di Sidoarjo; (2) Faktor-faktor apakah yang menyebabkan terjadinya konflik horisontal antar kelompok korban bencana Lumpur Lapindo di Sidoarjo; dan (3) Bagaimana bentuk-bentuk konflik horisontal antar kelompok korban bencana Lumpur Lapindo di Sidoarjo. Penelitian ini menggunakan pendekatan kualitatif, jenis penelitian studi kasus, teknik analisa data deskriptif-kualitatif, dan teknik pengumpulan data meliputi indeepth interview, Focus Group Discussion, observation, dan documentation. Hasil penelitian menunjukkan bahwa korban bencana Lumpur Lapindo membentuk kelompok sebagai wadah dalam memperjuangkan hakhak mereka. Terdapat dua kelompok utama korban bencana Lumpur Lapindo, yakni kelompok GKLL dan kelompok Pagarekorlap, namun kelompok ini mengalami friksi dan perpecahan dalam tiga hal yakni perubahan nama kelompok, bentuk tuntutan proses pembayaran ganti rugi, dan strategi aksi, sehingga menimbulkan konflik horisontal antara kelompok korban bencana Lumpur Lapindo dalam bentuk: konflik kepentingan, konflik strategi aksi, dan konflik mekanisme tuntutan ganti rugi.
\end{abstract}

Kata kunci: Bencana, Konflik, Kelompok.

\begin{abstract}
A phenomenon that became the focus of attention in this study is the phenomenon of conflict between groups of Lapindo mudflow disaster victims (Lula) in Sidoarjo. This study aims to assess: (1) How is the process of formation of the groups and conflict between groups Lapindo mudflow disaster victims in Sidoarjo?; (2) What factors are causing horizontal conflicts between groups Lapindo mudflow disaster victims in Sidoarjo?; and (3) How the forms of horizontal conflicts between groups Lapindo mudflow disaster victims in Sidoarjo?. This study used a qualitative approach, case study research, data analysis techniques descriptive qualitative, and data collection techniques include indeepth interviews, focus group discussions, observation, and documentation. The results showed that Lapindo mudflow disaster victims formed the group as a forum in Struggle their rights. There are two main groups of Lapindo mudflow disaster victims, namely GKLL groups and groups Pagarekorlap, however this group experienced friction and split in three ways ie change the group name, the form of demands compensation payment process, and action strategies, causing horizontal conflicts among groups Lapindo mudflow disaster victims in the form of: a conflict of interest, conflict action strategy, and conflict redress mechanism.
\end{abstract}

Keywords: Conflicts, Disasters, Group.

\footnotetext{
* Korespondensi: Prodi Ilmu Kesejahteraan Sosial, FISIP UMM, Jl. Raya Tlogomas No. 246 Malang, Tlp. (0341) 464318 Fax (0341) 460435.
} 


\section{Pendahuluan}

Konflik antar kelompok korban bencana Lumpur Lapindo muncul karena dipicu oleh adanya kebijakan pemerintah terkait penanganan dampak bencana Lumpur Lapindo. Dalam upaya penanganan dampak bencana Lumpur Lapindo, pemerintah menerbitkan Peraturan Presiden Nomor 14 tahun 2007 tertanggal 8 April 2007 tentang Badan Penanggulangan Lumpur Sidoarjo (BPLS) sebagai revisi atas Keputusan Presiden (Kepres) Nomor 13 Tahun 2006. Namun keluarnya Perpres tersebut justru telah mendorong munculnya kegelisahan dan kekhawatiran pada warga korban Lumpur Lapindo akan nasib mereka. Kekhawatiran warga korban Lumpur Lapindo terutama terkait substansi status mereka yang tidak diperlakukan sebagai korban bencana yang seharusnya mendapatkan ganti rugi, akan tetapi menjadi relasi antara penjual dan pembeli dalam skema penanganan masalah sosial kemasyarakatan. Dalam pasal 15 (1) Perpres Nomor 14 Tahun 2007 menyatakan bahwa: "Dalam rangka penanganan masalah sosial kemasyarakatan PT LBI membeli tanah dan bangunan masyarakat yang terkena luapan lumpur Sidoarjo dengan pembayaran secara bertahap, sesuai dengan peta area terdampak tanggal 22 Maret 2007 dengan akta jual beli bukti kepemilikan tanah yang mencantumkan luas tanah dan lokasi yang disahkan oleh Pemerintah".

Respons warga korban bencana Lumpur Lapindo terhadap kebijakan pemerintah yang dituangkan dalam Perpres Nomor 14 Tahun 2007 ini beragam, dimana ada yang setuju dan ada yang tidak setuju. Beragamnya respons warga korban bencana Lumpur Lapindo atas kebijakan pemerintah ini termanifestasikan dalam munculnya berbagai kelompok korban bencana Lumpur Lapindo. Diantara kelompokkelompok ini kemudian terjadi friksi dan konflik antar kelompok.

Apabila dicermati sebenarnya tuntutan dan keinginan warga korban bencana Lumpur Lapindo (Lula) sangat sederhana, yakni bagaimana agar mereka mendapatkan ganti rugi yang layak atas aset tanah dan bangunan hancur karena tergenang oleh luapan lumpur, serta direhabilitasinya kehidupan sosial mereka. Namun ketika tuntutan dan keinginan individu-individu warga korban bencana ini dikemas menjadi tuntutan bersama dalam suatu kelompok, maka persoalanya kemudian menjadi kompleks. Mengacu kepada pandangan Johnson dan Johnson (2000:16) bahwa kelompok dapat didefinisikan sebagai kumpulan sejumlah individu yang 
melakukan kerjasama untuk mencapai suatu tujuan bersama. Untuk mencapai tujuan bersama, maka suatu kelompok kemudian merumuskan taktik, strategi, dan cara-cara efektif untuk mencapai tujuan bersama tersebut. Konflik antar kelompok korban bencana Lumpur Lapindo terjadi karena terdapat perbedaan dalam strategi, taktik, dan kemasan kepentingan dalam memperjuang tuntutan ganti rugi. Friksi dan konflik yang terjadi antar kelompok korban bencana Lumpur Lapindo ini justru merugikan korban bencana Lumpur Lapindo sendiri karena memperlemah kekuatan dan posisi tawar mereka dengan pihak PT LBI dan pihak pemerintah.

Penelitian ini mencoba menggambarkan bagaimana konflik antar kelompok korban bencana Lumpur Lapindo terjadi. Permasalahan utama yang menjadi fokus pertanyaan penelitian ini adalah: Mengapa dan bagaimana terjadinya konflik antar kelompok korban bencana Lumpur Lapindo (Lula) di Sidoarjo?. Selanjutnya pertanyaan penelitian dielaborasi lagi menjadi beberapa sub-pertanyaaan, sebagai berikut: (1)Bagaimana proses terbentuknya kelompok-kelompok korban bencana Lumpur Lapindo hingga terjadinya konflik antar kelompok korban bencana Lumpur Lapindo di Sidoarjo?; (2) Faktor-faktor apakah yang menyebabkan terjadinya konflik horisontal antar kelompok korban bencana Lumpur Lapindo di Sidoarjo?; dan (3) Bagaimana bentuk-bentuk konflik horisontal antar kelompok korban bencana Lumpur Lapindo di Sidoarjo?

\section{Metode Penelitian}

Penelitian ini menggunakan paradigma interpretif-konstruktivis (constructivism-interpretive). Pendekatan penelitian yang digunakan adalah pendekatan kualitatif. Jenis atau metode penelitian yang digunakan adalah studi kasus (case study). Menurut Denzim dan Guba (Salim, 2001:89-101), studi kasus (case study) adalah merupakan salah satu metode dari penelitian dengan pendekatan kualitatif. Studi kasus adalah suatu pendekatan untuk mempelajari, menerangkan, atau menginterpretasi suatu kasus (case) dalam konteksnya secara natural tanpa adanya intervensi dari pihak luar.

Setting (lokasi) penelitian ditentukan secara purposive, yakni di wilayah yang terkena dampak Lumpur Sidoarjo, yakni di Kecamatan Porong, Jabon, dan Tanggulangin, Kabupaten Sidoarjo, Jawa Timur. Subjek dan informan penelitian 
ditentukan berdasarkan teknik purposive or judgemental sampling (Babbie, 2008:204; Neuman, 2007:142), meliputi: (1) masyarakat korban bencana lumpur Lapindo; (2) para pemimpin gerakan sosial; (3) koordinator paguyuban warga korban bencana; (4) tokoh masyarakat; (5) LSM peduli masyarakat korban Bencana; (6) PT LBI; (7) Pihak BPLS; (8) pihak Pemerintah, khususnya desa dan Kecamatan; dan (9) pihak DPRD Kabupaten Sidoarjo, khususnya Pansus Lumpur.

Dalam penelitian ini, secara garis besar proses pengumpulan data menggunakan 4 (empat) metode pokok yang saling berkaitan dan melengkapi, yaitu: (1) Wawancara mendalam (In-deepth Interview); (2) Observasi (observation); (3) Diskusi Kelompok Terfokus (Focus Group Discussion), dan (4) Dokumentasi (Documentation). Teknik kebasahan data difokuskan pada criteria kredibilitas (credibility) dan kepastian (confirmability). Teknik kredibilitas (credibility) yang digunakan adalah: perpanjangan keikutsertaan, ketekunan pengamatan, triangulasi, dan kecukupan referensial. Sedangkan teknik kepastian (confirmability) menggunakan teknik uraian rinci dan teknik audit kebenaran.

Mengingat data yang dihasilkan berupa data kualitatif, maka untuk menganalisisnya digunakan pendekatan interpretif (interpretive approach). Tahap-tahap proses data kualitatif mengacu kepada pendapat Babbie (2008:421), yakni: coding, memoing, dan concept mapping. Proses Coding, yaitu proses melakukan klasifikasi dan kategorisasi data, yang meliputi: open coding, axial coding dan selective coding. Proses Memoing, yaitu proses menulis memo atau catatan untuk diri sendiri dan orang lain yang terlibat dalam kegiatan penelitian. Proses memoing meliputi tiga jenis, yakni: Code Notes, Theoretical Notes, dan Operational Notes. Proses Concept Mapping, yaitu proses pemetaan relasi antar berbagai konsep. Pemetaan ini bisa berupa: alur, diagram, tabel, grafik, dsb.

\section{Hasil dan Pembahasan}

\section{Proses Terbentuknya Kelompok-Kelompok Korban Bencana Lumpur} Lapindo dan Terjadinya Konflik Antar Kelompok Korban Bencana Lumpur

\section{Lapindo}

Di lokasi pengungsian Pasar Baru Porong (PBP), beberapa tokoh masyarakat yang berasal dari wilayah desa yang terkena dampak bencana Lumpur Lapindo, yang juga merupakan korban bencana, karena merasa terpanggil dan atas 
dasar tanggung jawab sosial kemudian tampil sebagai insiator dalam menggkoordinir warga korban bencana Lumpur Lapindo. Para tokoh masyarakat tersebut kemudian mulai melakukan konsolidasi, rapat-rapat, diskusi, dan pertemuan-pertemuan bersama dengan warga korban bencana Lumpur Lapindo yang lainnya. Dari proses tersebut maka kemudian disepakati untuk dibentuk kelompok korban bencana Lumpur Lapindo yang selanjutnya dijadikan basis bagi gerakan sosial korban bencana Lumpur Lapindo dalam melawan bentuk ketidakadilan yang mereka rasakan.

Dalam proses selanjutnya, kemudian lahirlah dua kelompok utama korban bencana Lumpur Lapindo, yakni kelompok: (1) Gabungan Korban Lumpur Lapindo (GKLL); dan (2) Paguyuban Warga Renokenongo Korban Lapindo (Pagarekorlap). Proses terbentuknya kelompok korban bencana Lumpur Lapindo tersebut dapat diuraikan sebagai berikut:

Pertama; Proses Terbentuknya Kelompok Gabungan Korban Lumpur Lapindo (GKLL). Pada sekitar bulan Agustus 2007, warga korban bencana lumpur Lapindo membentuk sebuah kelompok yang menamakan diri Gabungan Korban Lumpur Lapindo (GKLL). Anggota GKLL adalah para warga korban bencana lumpur Lapindo, terutama yang berasal dari Desa Siring, Jatirejo, Renokenongo, Kedungbendo, dan warga Perumahan Tanggul Angin Sejahtera (Perum TAS), yang jumlahnya lebih dari $5.000 \mathrm{KK}$. Berdasarkan kesepatan warga korban, kemudian Djoko Suprastowo diberikan kepercayaan sebagai Koordinator GKLL dan Khoirul Huda sebagai skretaris GKLL. Untuk memperkuat jaringan kelompok, selanjutnya dibentuk pengurus GKLL di tingkat desa dan kelurahan, yang meliputi: Bambang Harpriyatno (Koordintaor GKLL Kelurahan Siring), M. Saudo (Koordintaor GKLL Desa Renokenongo), H. Imron Rosadi (Koordintaor GKLL Desa Kedungbendo I), Suparman (Koordintaor GKLL Desa Kedungbendo II), H. Suprat (Koordintaor GKLL Desa Jatierjo), M. Mufid (Koordintaor GKLL Desa Ketapang), Agus Cahyono (Koordintaor GKLL Desa Kalitengah), dan Sutikno (Koordintaor GKLL Desa Gempolsari).

Khoirul Huda merupakan orang yang paling dominan dalam menggerakkan kelompok GKLL, sehingga Khoirul Huda menjadi tokoh sentral dalam kelompok GKLL. Menurut penuturan Khoirul Huda, dulu sebelum terjadinya peristiwa semburan lumpur Lapindo dia merupakan tokoh Desa Jatirejo dan 
memegang jabatan sebagai Wakil Ketua Lembaga Pemberdayaan Masyarakat (LPM) desa Jatirejo.

Kedua; Proses Terbentuknya Kelompok Paguyuban Warga Renokenongo Korban Lumpur Lapindo (Pagarekorlap). Selain kelompok GKLL, juga muncul kelompok lainnya yang menamakan diri Paguyuban Warga Renokenongo Korban Lumpur Lapindo (Pagarekorlap). Anggota kelompok Pagarekorlap meliputi seluruh warga korban bencana lumpur Lapindo yang berasal dari desa Renokenongo, Kecamatan Porong, yang tinggal di tempat pengungsian Pasar Baru Porong (PBP), yang jumlahnya sekitar 766 KK. Koordinator kelompok Pagarekorlap dipercayakan kepada H. Sunarto, sedangkan sekretarisnya Pitanto.

Pitanto $^{\dagger}$ menjelaskan bahwa ketika warga yang menjadi korban bencana Lumpur Lapindo berada di pengungsian Pasar Baru Porong (PBP) kondisinya sangat memprihatinkan dan banyak yang resah. Selanjutnya bersama dengan H. Sunarto, SE., Pitanto mengumpulkan beberapa warga korban Lumpur Lapindo yang ada di tempat pengungsian Pasar Porong Baru (PPB) untuk mendiskusikan dan membicarakan tentang kondisi dan nasib mereka. Warga korban bisa dikumpulkan melalui informasi dari mulut ke mulut secara "gethok tular". Dari diskusi dan pembicaraan informal dengan beberapa warga korban bencana Lumpur Lapindo ini kemudian disepakati untuk membentuk suatu kelompok yang bisa mewakili warga korban dalam memperjuangkan nasibnya. Maka, selanjutnya dibentuk sebuah kelompok yang diberi nama Paguyuban Warga Renokenongo Korban Lumpur Lapindo (Pagarekorlap).

Nama Renokenongo mengacu kepada desa asal warga korban yang berada di tempat pengungsian Pasar Baru Porong (PBP), yakni Desa Renokenongo. Kemudian warga juga sepakat secara aklamasi untuk memilih H. Sunato, SE., untuk menjadi Koordinator dan Pitanto untuk menjadi Wakil Koordintanor kelompok Pagarekorlap. Untuk melengkapi kepengurusan, selanjutnya H. Sunarto, SE., dan Pitanto meminta Yudo Wintoko sebagai sekretaris dan Aris Setiadi sebagai bendahara kelompok Pagarekorlap. Dari uraian diatas, selanjutnya secara ringkas dapat digambarkan dalam bentuk tabel sebagai berikut:

† Pitanto, laki-laki, usia 51 tahun, asal Desa Renokenongo, adalah Wakil Ketua Kelompok Pagarekontrak. 
Tabel 1. Proses Terbentuknya Kelompok Korban Bencana Lumpur Lapindo

\begin{tabular}{c|l|l|l} 
No. & Nama Kelompok & $\begin{array}{l}\text { Proses Terbentuknya } \\
\text { Kelompok }\end{array}$ & $\begin{array}{l}\text { Tokoh Pemimpin } \\
\text { Kelompok }\end{array}$ \\
\hline 1. & $\begin{array}{l}\text { Gabungan Korban } \\
\text { Bencana Lumpur } \\
\text { Lapindo (GKLL) }\end{array}$ & $\begin{array}{l}\text { Dibentuk di lokasi } \\
\text { pengungsian Pasar } \\
\text { Porong Baru (PPB) atas } \\
\text { inisiatif tokoh masyarakat } \\
\text { desa Jatirejo. }\end{array}$ & $\begin{array}{l}\text { Djoko Suprastowo } \\
\text { dan Khoirul Huda }\end{array}$ \\
\hline 2. & $\begin{array}{l}\text { Paguyuban Warga } \\
\text { Renokenongo Korban } \\
\text { Lumpur Lapindo } \\
\text { (Pagarekorlap) }\end{array}$ & $\begin{array}{l}\text { Dibentuk di tempat } \\
\text { pengungsian Pasar Baru } \\
\text { Porong (PBP) atas } \\
\text { inisiatif tokoh desa } \\
\text { Renokenongo. }\end{array}$ & Sunarto dan Pitanto \\
\end{tabular}

\section{Faktor-faktor Penyebab Terjadinya Konflik Horisontal Antar Kelompok Korban Bencana Lumpur Lapindo:}

Konflik horisontal antar kelompok korban bencana Lumpur Lapindo terjadi karena adanya friksi di antara kelompok tersebut. Friksi tersebut muncul dalam tiga hal. Pertama, Friksi dalam perubahan nama kelompok. Ketika pengadilan menyatakan bahwa PT LBI dinyatakan tidak bersalah atas terjadinya semburan lumpur panas di Sidoarjo maka dinamika gerakan sosial korban bencana Lumpur Lapindo mengalami perubahan yang cukup signifikan. Perubahan terjadi antara lain pada nama kelompok (organisasi) gerakan sosial korban bencana Lumpur Lapindo dan perubahan atas strategi gerakan yang dilakukan kelompok (organisasi) korban Lumpur Lapindo tersebut.

Nama GKLL yang semula merupakan singkatan dari Gabungan Korban Lumpur Lapindo, kemudian berubah manjadi Gabungan Korban Luapan Lumpur. Terdapat perubahan nama dari Lapindo menjadi Lumpur, namun nama kelompoknya masih tetap GKLL. Perubahan nama ini didasarkan atas pertimbangan keluarnya penetapan Mahkamah Agung (MA) yang menyatakan bahwa PT LBI dinyatakan tidak bersalah atas terjadinya bencana semburan lumpur di Sidoarjo, dan dinyatakan bahwa fenomena semburan lumpur di Sidoarjo dikategorikan sebagai bencana alam.

Kedua, Friksi dalam perubahan bentuk tuntutan skema proses pembayaran ganti rugi. Selain terjadinya perubahan singkatan nama kelompok GKLL, juga terdapat perubahan tuntutan proses ganti rugi dari skema cash and carry $(\mathrm{CnC})$ menjadi cash and resttlement $(C n R)$ yang dilakukan oleh pengurus GKLL, dan 
penggantian nama GKLL menjadi Gabungan Korban Luapan Lumpur, telah menimbulkan kekecewaan pada sebagian warga korban bencana Lumpur Lapindo yang menjadi anggota GKLL karena keputusan tersebut diambil secara sepihak tanpa melalui musyawarah dan kesepakatan warga. Selanjutnya, warga korban lumpur Lapindo yang tidak setuju dengan perubahan GKLL kemudian mereka mendirikan kelompok "perjuangan baru” yang menamakan diri kelompok Gepres, singkatan dari Gerakan Pendukung Perpres Nomor 14/2007. Selain Gepres, juga muncul kelompok lainnya yakni yang menamakan diri Tim-16. Dengan demikian kelompok Geppres dan Tim 16 lahir karena munculnya ketidakpuasan dari sebagian warga korban lumpur Lapindo terhadap kebijakan GKLL yang tidak lagi mampu memperjuangkan aspirasi mereka. Kelompok Geppres merupakan kelompok pecahan dari kelompok GKLL. Pada tanggal 24 Juni 2008, GKLL yang awalnya menuntut skema "Cash and Carry” $(C n C)$ menandatangani nota kesepahaman dengan PT MLJ untuk menerima skema "cash and resettlement" (CnR), disaksikan oleh Bupati, Kepala BPLS dan Cak Nun selaku pembina GKLL. Karena nota kesepahaman itulah kemudian banyak warga yang kecewa yang kemudian membentuk kelompok Gabungan Pendukung Perpres (Geppres).

Geppres dipimpin oleh seorang tokoh agama, yakni KH. Abdul Fatah, yang merupakan pengasuh di Pondok Pesantren At-Tahzib, Karang Bendo, Tanggulangin, Sidoarjo. KH. Abdul Fatah dipilih oleh warga korban lumpur Lapindo sebagai Koordinator Gepres. Selain KH. Abdul Fatah, ada juga tokoh Geppres yakni Machmudatul Fatchiyah yang merupakan mantan Kepada Desa Renokenongo. Anggota Geppres, terdiri dari sebagian warga Perum TAS dan warga desa Jatiredjo, Siring, Kedung Bendo, dan Renokenongo, Desa Besuki, Kedungcangkring, dan Penjarakan, yang mayoritas tidak memiliki sertifikat tanah. Bukti kepemilikan tanah yang mereka miliki kebanyakan adalah Letter-C atau Petok-D.

Kelompok pecahan lainnya dari GKLL adalah kelompok Tim-16. Kelompok Tim-16 terdiri dari mayoritas warga Perumahan Tanggul Angin Sejahtera (Perum TAS) yang semuanya memiliki sertifikat tanah.Kelompok Tim-16 muncul karena tidak setuju dengan skema "cash and resettlement" (CnR) yang diperjuangkan oleh GKLL. Kelompok ini mengajukan tuntutan berupa relokasi. Koordinator kelompok Tim-16 adalah bapak Subiyanto dan tokoh lainnya adalah bapak Suharso. Anggota 
kelompok Tim-16 sekitar 2.000 orang yang merupakan warga yang tinggal di Perumahan Tanggul Angin Sejahtera (Perumtas).

Ketiga, Friksi atas perubahan strategi aksi kelompok. Strategi kooperatif yang dilakukan GKLL menyebabkan munculnya sindiran sinis dari berbagai kelompok lainnya. Prinsip GKLL sekarang lebih banyak berdiskusi dengan pihak PT LBI dalam mencari solusi ketimbang konfrontasi. Kedekatan GKLL dengan PT LBI memunculkan anggapan bahwa GKLL sebagai "anak emasnya" Bakrie. Ketika Aburizal Bakrie (ARB) mencalonkan diri sebagai Ketua Umum Partai Golkar, GKLL pun memberikan dukungannya. Demikian pula ketika ARB memunculkan diri sebagai Calon Presiden RI 2014-2019, GKLL pun memberikan dukungannya. Sementara kelompok-kelompok yang lain malah menghujat ARB yang dianggap tidak pantas menjadi Ketua Umum Partai Golkar apalagi menjadi Presiden. Atas kedekatan ini kemudian, sekretaris GKLL yakni Khoirul Huda mendapatkan keuntungan politik karena diusung oleh Partai Golkar untuk menjadi Calon Wakil Bupati Sidoarjo dalam Pilkada Kabupaten Sidoarjo periode 2010-2015, meskipun kalah. Pada tahun 2012, Khoirul Huda juga merapat ke Partai Golkar dan menjadi salah satu Caleg Partai Golkar untuk Pemilu Legislatif 2014-2019.

Mengenai dukungan GKLL terhadap ARB baik sebagai Ketua Umum Partai Golkar maupun sebagai calon Presiden, Khoirul Huda memberikan alasan yang rasional bahwa itu juga sebagai bagian dari strategi perjuangan. Sebab jika ARB menjadi Ketua Umum Partai Golkar dan menjadi calon Presiden maka masalah lumpur Lapindo pasti akan diselesaikan, karena terlalu beresiko secara politik jika masalah lumpur Lapindo terkatung-katung. Menurut pandangan GKLL, kelompok-kelompok korban lumpur Lapindo yang lainya tidak memahami permasalahan yang sebenarnya, sehingga strateginya lebih bersifat emosional dan konfrontatif daripada kooperatif. Sementara kelompok-kelompok yang lainnya menganggap pihak GKLL sebagai penghianat.

Berbeda dengan kelompok GKLL, strategi perjuangan kelompok Pagarekontrak adalah: negosiasi, konsolidasi, dan konfrontasi. Negosiasi dilakukan ketika Pagarekontrak memperjuangkan tuntutan warga korban bencana Lumpur Lapindo kepada pihak PT LBI, jika negosiasi tidak berhasil kemudian Pagarekontrak melakukan konsolidasi kekuatan untuk melakukan tekanan-tekanan. Apabila negosiasi 
dan konsolidasi ini tidak berhasil maka strategi berikutnya adalah dengan cara konfrontatif. Menurut Sunarto $\ddagger$, strategi perjuangan Pagarekontrak masih "kencang" tidak seperti GKLL yang mulai mengendur. Menurutnya kelompokwarga korban bencana Lumpur Lapindo yang lainnya yang masih dianggap "kencang" menyuarakan aspirasi warga korban adalah kelompok Gerakan Pendukung Perpres (Gepres).

Sementara itu kelompok-kelompok yang lainnya pada awalnya sebagian besar menggunakan strategi konfrontatif, namun seiring dengan semakin melemahnya kekuatan kelompok, maka strateginya melunak menjadi akomodatif. Misalnya, kelompok Geppres yang semula menuntut model penyelesaian ganti rugi dengan mengacu kepada Perpres, namun kemudian melunak dan menyetujui model relokasi. Kelompok Tim-16 yang semula juga menuntut hal yang sama seperti kelompok Geppres, namun akhirnya juga melunak dengan menyetujui model "cash and resettlement" dan sebagaian menyetujui model relokasi ke KNV. Dari uraian diatas, selanjutnya secara ringkas dapat digambarkan dalam bentuk tabel sebagai berikut:

Tabel 2. Faktor Penyebab Konflik Antar-Kelompok Korban Bencana Lumpur Lapindo

\begin{tabular}{c|l|l}
\hline No. & \multicolumn{1}{|c}{ Faktor Penyebab Konflik } & \multicolumn{1}{c}{ Uraian } \\
\hline 1. & $\begin{array}{l}\text { Friksi dalam perubahan nama } \\
\text { kelompok }\end{array}$ & $\begin{array}{l}\text { Konflik terjadi karena dipicu oleh perubahan } \\
\text { nama kelompok. Misalnya nama kelompok } \\
\text { Gabungan Korban Lumpur Lapindo (GKLL) } \\
\text { berubah menjadi kelompok Gabungan } \\
\text { Korban Luapan Lumpur (GKLL), kemdian } \\
\text { nama kelompok Paguyuban Warga } \\
\text { Renokenongo Korban Lumpur Lapindo } \\
\text { (Pagarekorlap) berubah menjadi kelompok } \\
\text { Paguyuban Warga Renokenongo Menolak } \\
\text { Kontran (Pagarekontrak). }\end{array}$ \\
\hline 2. & $\begin{array}{l}\text { Friksi dalam perubahan bentuk } \\
\text { tuntutan skema proses } \\
\text { pembayaran ganti rugi }\end{array}$ & $\begin{array}{l}\text { Konflik dipicu oleh adanya perubahan dan } \\
\text { perbedaan bentuk tuntutan skema proses } \\
\text { pembayaran ganti rugi dari bentuk Cash and } \\
\text { Carry, Cash dan Cicilan, dan Cash and } \\
\text { Ressetlement. }\end{array}$ \\
\hline 3. & $\begin{array}{l}\text { Friksi atas perubahan strategi } \\
\text { aksi kelompok }\end{array}$ & $\begin{array}{l}\text { Konflik dipicu oleh adanya perubahan strategi } \\
\text { aksi dari konfrontatif menjadi kooperatif, } \\
\text { negosiatif, dan akomodatif. }\end{array}$ \\
\hline
\end{tabular}

¥ Sunarto adalah Koordinator Pagarekontrak. 


\section{Bentuk-bentuk Konflik Horisontal Antar Kelompok Korban Bencana Lumpur Lapindo di Sidoarjo:}

Konflik horisontal antar kelompok korban bencana Lumpur Lapindo dapat dikategorikan ke dalam tiga bentuk konflik. Pertama, Konflik kepentingan yang berbeda antara para pemimpin gerakan sosial. Pada awalnya, kepentingan (dorongan) para pemimpin melakukan upaya mengkoordinir korban bencana Lumpur Lapindo untuk sebuah gerakan sosial karena merasa prihatin atas nasib dan kondisi warga korban bencana Lumpur Lapindo. Pada awalnya ada kepentingan sosial (tanggung jawab sosial) yang mendasari tindakan pemimpin dalam mengkoordinir warga korban bencana Lumpur Lapindo untuk melakukan gerakan social melawan ketidakadilan. Dalam perkembangan selanjutnya, terdapat kepentingan-kepentingan yang menyertai para pemimpin gerakan sosial korban bencana Lumpur Lapindo, tidak hanya sekedar kepentingan tanggung jawab sosial saja akan tetapi juga ada kepentingan politik dan ekonomi.

Sebagai contoh, seperti yang telah disinggung di atas, Khoirul Huda sebagai pemimpin kelompok GKLL memiliki motif politik dan kekuasaan sebagai sertaannya. Keterlibatan Khoirul Huda dalam perjuangan warga korban bencana Lumpur Lapindo, menyebabkan namanya menjadi terkenal. Dengan memanfaatkan kekuatan GKLL sebagai representasi dari korban bencana Lumpur Lapindo, Khoirul Huda kemudian terlibat di dunia politik untuk mendapatkan kekuasaan. Faktanya adalah bahwa Khoirul Huda pernah menjadi calon Wakil Bupati Sidoarjo untuk peridose 2010-2015 mendampingi Bambang Prasetyo Widodo sebagai calon Bupati Sidoarjo. Pasangan Cabup-Cawabup Sidoarjo Bambang Prasetyo Widodo-Khoirul Huda (Setia Huda) resmi mendaftarkan diri ke Komisi Pemilihan Umum (KPU) Daerah Sidoarjo, pada hari Minggu tanggal 2 Mei 2010. Pasangan ini diusung oleh koalisi beberapa partai, seperti Partai Demokrasi Indonesia (PDI Perjuangan), Partai Kebangkitan Nasional Ulama (PKNU), Partai Golongan Karya (Golkar) dan Partai Hati Nurani Rakyat (Hanura). Partai Golkar merupakan partai utama yang mengusung Khoirul Huda untuk menjadi calon Wakil Bupati Kabupaten Sidoarjo periode 20102015.

Mengapa Khoril Huda diusung oleh Partai Golkar? Pertanyaan ini menarik karena sebagaiman diketahui bahwa PT LBI tidak bisa dilepaskan dari sosok ARB, 
sementara ARB adalah Ketua Umum Partai Golkar. Menurut penjelasan Khoirul Huda bahwa dirinya diusung oleh Partai Golkar karena sebelumnya Partai Golkar yang memberinya kartu anggota yang secara resmi menjadi kader Partai Golkar. Mengapa Partai Golkar memberikan kartu anggota partai kepada Khoirul Huda? Hal ini nampaknya sebagai “relasi balas budi” Partai Golkar kepada Khoirul Huda. Sebagaimana sudah dijelaskan di Bab IV bahwa ketika ARB mencalonkan diri sebagai Ketua Umum Partai Golkar, kelompok GKLL yang dimotori oleh Khoirul Huda menyatakan memberikan dukungan sepenuhnya. Demikian pula ketika ARB menyatakan mencalonkan diri untuk menjadi calon Presiden RI untuk periode 20141019 kelompok GKLL dan Khoirul Huda menyatakan memberikan dukungan. Sementara kelompok dan pemimpin korban bencana Lumpur Lapindo yang laiinya justru menentangnya.

Relasi politik antara Khoirul Huda dan Partai Golkar kemudian terus berlanjut. Dalam Pemilu Legislatif 2014 Khoirul Huda kemudian menjadi Calon Anggota Legislatif (Caleg) DPRD Kabupaten Sidoarjo yang disung oleh Partai Golkar. Dalam Pileg tahun 2014 ini, akhirnya Khoirul Huda terpilih menjadi anggota DPRD Kabupaten Sidoarjo untuk periode 2014-2019. Kiprah Khoirul Huda ini, tidak terlepas dari posisinya sebagai sekretaris kelompok GKLL. Maka dengan demikian dapat dinyatakan bahwa ada motif politik dan kekuasaan yang menyertai Khoirul Huda sebagai pemimpin gerakan social korban bencana Lumpur Lapindo, selain motif awalnya yakni motif social atau motif tanggung jawab sosial.

Berbeda dengan pemimpin sentral GKLL, kepentingan lain dari pemimpin kelompok Pagarekontrak lebih cenderung kepada relasi ekonomi (bisnis). Aspirasi warga korban bencana Lumpur Lapindo yang tergabung dalam kelompok Pagarekontrak ini meminta agar tempat tinggal mereka yang baru bisa direlokasikan di satu tempat, sehingga mereka bisa berkumpul bersama sebagaimana dulu saat tinggal di Desa Renokenongo. Aspirasi warga korban bencana Lumpur Lapindo yang tergabung dalam kelompok Pagarekontrak yang menginginkan untuk relokasi tempat tinggal secara bersama-sama di tempat yang baru kemudian direspons oleh para pemimpin kelompok Pagarekontrak. Para pemimpin kelompok Pagarekontrak kemudian mencari lokasi tanah untuk kawasan perumahan dan membangun rumah untuk hunian korban bencana Lumpur Lapindo melalui kerjasama dengan Real Estate 
Indonesia (REI) Jatim dan Bank Jatim, yang difasilitasi pihak Gubernur Jawa Timur dan Pemerintah Kabupaten (Pemkab) Sidoarjo. Selanjutnya, maka diatas tanah seluas sepuluh hektar dibangun sekitar 600 unit rumah tipe 36 yang kemudian menjadi kawasan Perumahan Renojoyo. Nama Renojoyo diambil dari nama asal desa warga korban bencana Lumpur Lapindo yakni Desa Renokenongo. Dalam konteks ini, para pemimpin kelompok Pagarekontrak yakni Sunarto, Pitanto, Yudi Wintoko, dan Aris Setiadi lebih banyak berperan sebagai broker pengembang perumahan. Disinyalir bahwa mereka ini telah mendapatkan fee dari upayanya dalam membantu pembebasan tanah dan pembangunan kawasan perumahan di Renojoyo.

Selain itu, mobilisasi sumber dana financial dari korban bencana Lumpur Lapindo juga merupakan aspek yang potensial. Dari aspek financial, potensi dana yang bersumber dari iuran (tarikan) yang dikumpulkan (dimobilisir) dari setiap warga korban bencana Lumpur Lapindo memang cukup besar. Misalnya, jumlah berkas jual-beli asset tanah dan bangunan milik warga korban bencana Lumpur Lapindo yang tergabung dalam kelompok GKLL sebanyak 4000 berkas. Setiap berkas ditarik iuran (fee) sebesar Rp 500.000,-(Limaratus Ribu Rupiah) yang disetorkan kepada kas bendahara kelompok GKLL. Dengan demikian dana yang terkumpul di bendahara GKLL mencapai jumlah sekitar 2 Milyar.

Demikian pula untuk kelompok Pagarekontrak, seperti halnya kelompok GKLL, warga korban bencana Lumpur Lapindo yang tergabung dalam kelompok Pagarekontrak juga ditarik iuran (fee) untuk masing-masing berkas antara 500 Ribu Rupiah hingga satu juta Rupiah. Jika diasumsikan ada 600 Kepala Keluarga (KK) yang menjadi anggota kelompok Pagarekontrak dimana masing-masing KK memiliki satu berkas, apabila masing-masing berkas ditarik iuran (fee) sebesar 500 Ribu Rupiah saja, maka jumlah dana yang terkumpul di kas Bendahara kelompok Pagarekontrak mencapai sekitar 300 juta Rupiah. Dana iuran dari warga ini kemudian dikelola oleh bendahara untuk dijadikan dana perjuangan kelompok Pagarekontrak.

Dalam proses perjalanan gerakan sosial korban bencana Lumpur Lapindo, para pemimpin gerakan melihat berbagai peluang yang muncul di luar konteks kepentingan utama gerakan sosial. Peluang-peluang tersebut bisa berupa peluang politik, konomi, sosial, dan sebagainya. Berbagai peluang tersebut kemudian dimanfaatkan oleh para pemimpin gerakan social korban bencana Lumpur Lapindo 
untuk tujuan-tujuan yang cenderung bersifat interes pribadi. Sebagian besar para pemimpin kelompok korban bencana Lumpur Lapindo memiliki latar belakang pengusaha atau wiraswasta. Sehingga insting sebagai pengusaha dalam melihat peluang-peluang yang muncul, terutama peluang ekonomi sangat dimungkinkan dalam proses dan dinamika perjalanan gerakan social korban bencana Lumpur Lapindo.

Kedua, Konflik strategi gerakan sosial. Pada periode awal gerakan, yakni sebelum adanya penetapan pihak pengadilan bahwa peristiwa bencana semburan Lumpur Lapindo di Sidoarjo sebagai bencana alam, strategi gerakan yang digunakan oleh kelompok-kelompok korban bencana Lumpur Lapindo dengan menggunakan strategi konfrontatif. Sedangkan bentuk aksi gerakan lebih banyak menggunakan aksi pengerahan massa seperti demonstrasi. Jadi dalam melakukan aksi gerakan sosial, kedua kelompok gerakan sosial korban Lumpur Lapindo yakni kelompok GKLL dan kelompok Pagarekorlap menggunakan strategi konfrontatif. Ada tiga hal prinsip yang diperjuangkan GKLL melalui strategi konfrontatif, yakni: masalah penentuan dan tuntutan ganti rugi, besaran biaya ganti rugi yang harus dibayarkan kepada warga korban lumpur Lapindo, dan persoalan alat bukti kepemilikan aset warga korban lumpur Lapindo. Strategi konfrontatif ini berhasil dengan keluarnya Perpres Nomor 14 Tahun 2007 tentang Badan Penanggulangan Lumpur Sidoarjo (BPLS), tertanggal 28 April 2007, sebagai payung hukum.

Menurut penjelasan Pitanto, strategi perjuangan kelompok Pagarekontrak adalah: negosiasi, konsolidasi, dan konfrontasi. Negosiasi dilakukan ketika Pagarekontrak memperjuangkan tuntutan warga korban bencana Lumpur Lapindo kepada pihak PT LBI, jika negosiasi tidak berhasil kemudian Pagarekontrak melakukan konsolidasi kekuatan untuk melakukan tekanan-tekanan. Apabila negosiasi dan konsolidasi ini tidak berhasil maka strategi berikutnya adalah dengan cara konfrontatif. Strategi konfrontatif yang dilakukan oleh kelompok GKLL dan Pagarekorlap dikarenakan warga korban bencana Lumpur Lapindo menganggap bahwa pihak PT LBI sebagai pihak yang bertanggungjawab atas terjadinya bencana dan pihak pemerintah lamban dalam mengambil tindakan untuk mengatasi dampak bencana.

Perubahan strategi aksi kelompok terjadi karena posisi PT LBI yang dinyatakan tidak bersalah oleh pengadilan. Pihak PT LBI, sebagaimana dinyatakan Aburizal Bakrie, mengaku tidak merasa bersalah atas terjadinya bencana semburaan 
Lumpur Lapindo Sidoarjo. Meski begitu, pihaknya tetap memberikan ganti rugi dengan cara membeli tanah dan bangunan warga lantaran "titah ibundanya". Menurut Aburizal Bakrie, pihak PT LBI sudah dinyatakan tidak bersalah oleh pihak MA, dengan demikian keputusannya sudah berkekuatan hukum tetap. Hanya saja, karena "sang ibu" memerintahkan Aburizal Bakrie untuk membeli tanah dan bangunan, maka dia mengaku mematuhinya. Aburizal Bakrie menjelaskan tanah dan bangunan milik warga itu itu bukan ganti rugi, melainkan melalui proses jual beli dengan harga Nilai Jual Objek Pajak (NJOP) yang seharusnya sebesar Rp 60.000 per-meter persegi, tetapi dihargai oleh PT LBI sebesar Rp 1 juta.

Pertimbangan yang lainnya yang menyebabkan terjadinya perubahan strategi GKLL dari strategi konfrontatif ke strategi koopertif adalah berkaitan dengan fakta tentang posisi keluarga Bakrie dalam kepemilikan saham PT LBI. Saham PT LBI dimiliki oleh tiga perusahaan, yakni: Energy Mega Persada (EMP) sebesar 50\%, Medco Energy Persada sebesar 32\%, dan Santos sebesar 18\%. Dari saham EMP sebesar 50\%, kemudian kepemilikannya dibagi dua yakni keluarga Bakrie memiliki saham sebesar $50 \%$ dan sisanya 50\% dimiliki oleh publik. Medco hanya mau melakukan pembayaran ganti rugi dengan menanggung 30\% saja dari total dana ganti rugi jika PT LBI dinyatakan bersalah oleh pengadilan. Namun ternyata karena pengadilan menyatakan bahwa PT LBI tidak bersalah, maka Medco pun "lari". Sementara Santos hanya mengeluarkan dana sebesar Rp 600 juta untuk kepentingan menutup rig (snubbing units). Maka tinggal keluarga Bakrie yang "tegap berdiri” dalam menyelesaikan pembayaran ganti rugi, meskipun dinyatakan tidak bersalah oleh MA. Sementara di sisi lainnya, kepemilikan keluarga Bakrie di PT LBI juga tidak begitu signifikan.

Ketiga, Konflik tentang mekanisme pembayaran ganti rugi. GKLL memperjuangkan proses ganti rugi bagi warga korban lumpur Lapindo melalui skema cash and carry $(C n C)$, sebagaimana diatur dalam Perpres Nomor 14 Tahun 2007. Skema cash and carry adalah skema pembayaran ganti rugi secara bertahap melalui pembayaran uang muka sebesar $20 \%$, dan sisanya sebesar $80 \%$ dilunasi dengan cara pembayarn tunai dalam kurun waktu 2 tahun. Selama 2 tahun warga korban akan diberikan uang untuk kontrak rumah sebasar Rp 5 juta, dan jatah hidup sebesar Rp 300 ribu untuk setiap jiwa perbulan. Sementara kelompok Tim-16 menuntut mekanisme cash and resettlement $(\mathrm{CnR})$. Konsep skema Cash and Resettlement $(\mathrm{CnR})$ adalah bersifat: (1) Cash, 
meliputi pembayaran hanya untuk bangunan dihargai $\mathrm{Rp} 1,5$ juta/meter, dan realisasi pembayaran 2 bulan setelah penandatanganan; (2) Resettlement, melalui penggantian tanah dengan perbandinagan 1:1; Lokasi dikawasan PT Kahuripan Nirwana Village (KNV); untuk tanah sawah di Desa Sambibulu, Kecamatan Taman, Kabupaten Sidoarjo. Sedangkan kelompok Pagarekontrak menuntut mekanisme Resettlement. Dari uraian diatas, selanjutnya secara ringkas dapat digambarkan dalam bentuk tabel sebagai berikut:

Tabel 3. Bentuk-Bentuk Konflik Antar-Kelompok Korban Bencana Lumpur Lapindo

\begin{tabular}{c|l|l}
\hline No. & Bentuk Konflik & Uraian \\
\hline 1. & Konflik Kepentingan & $\begin{array}{l}\text { Adanya bias antar kepentingan politik dan } \\
\text { kepentingan ekonomi bisnis) pada aktor } \\
\text { pemimpin kelompok korban bencana Lumpur } \\
\text { Lapindo. }\end{array}$ \\
\hline 2. & Konflik Strategi Aksi & $\begin{array}{l}\text { Konflik strategi ditandai oleh terjadinya } \\
\text { perbedaan antara strategi konfrontatif, } \\
\text { negosiatif, akomodatif dan koopeartif diantara } \\
\text { kelompok korban bencana Lumpur Lapindo. }\end{array}$ \\
\hline 3. & $\begin{array}{l}\text { Konflik Mekanisme } \\
\text { Ganti Rugi }\end{array}$ & $\begin{array}{l}\text { Konflik ditandai dengan munculnya berbagai } \\
\text { bentuk tuntutan mekanisme ganti rugi diantara } \\
\text { kelompok korban bencana Lumpur Lapindo, } \\
\text { yakni dalam bentuk Cash and Carry, Cash dan } \\
\text { Cicilan, dan Cash and Ressetlement. }\end{array}$ \\
\hline
\end{tabular}

Konflik yang terjadi antar kelompok korban bencana Lumpur Lapindo bukan merupakan bentuk konflik vertikal akan tetapi lebih sebagai bentuk konflik horisontal. Bentuk konflik vertikal ditandai dengan pelibatan dua pihak atau lebih yang memiliki posisi dan kekuasaan berbeda. Berbeda dengan bentuk konflik vertikal, dalam konflik horisontal posisi dan kekuasaan di antara kelompok-kelompok (pihakpihak) yang berkonflik dalam keadaan yang setara. Menurut Fisher (Deutsh, Coleman, \& Marcus, 2006:178), esensi dari konflik antar kelompok ditandai oleh tiga elemen, yakni: ketidakserasian (incompatibilities), tingkah laku (behaviors), dan setimen (sentiments). Oleh karena itu konflik antar kelompok korban bencana Lumpur Lapindo lebih diakibatkan oleh adanya ketidakserasian dalam menentukan taktik dan strategi tuntutan ganti rugi terhadap pihak PT LBI dan pihak pemerintah. Ketidakserasian taktik dan strategi tuntutan ganti rugi kemudian memunculkan perasaan sentimen dan perilakuperilaku yang tidak bersesuaian antar kelompok korban bencana Lumpur Lapindo. 
Dalam konteks bencana Lumpur Lapindo sebenarnya terjadi dua bentuk konflik, yakni konflik vertikal dan konflik horisontal. Konflik vertikal terjadi antara kelompok-kelompok korban bencana Lumpur Lapindo dengan pihak PT LBI dan pihak pemerintah, sedangkan konflik horisontal terjadi antar kelompok-kelompok korban bencana Lumpur Lapindo itu sendiri. Para korban bencana Lumpur Lapindo seharusnya mereka bersatu untuk melakukan tuntutan ganti rugi kepada pihak PT LBI dan pihak pemerintah karena mereka merupakan korban dari kebijakan pemerintah yang memberikan ijin eksplorasi Migas kepada pihak PT LBI. Namun justru ternyata diantara kelompok-kelompok korban bencana Lumpur Lapindo itu sendiri terpecah dan terjadi konflik.

Konflik berasal dari kata confligere, conflicium, yang artinya saling berbenturan, adalah semua bentuk benturan, tabrakan, ketidakserasian, pertentangan, perkelahian, oposisi dan interaksi-interaksi yang antagonistis-bertentangan (Kartono, 1983: 245). Konflik dapat juga diartikan sebagai proses pencapaian tujuan dengan cara melemahkan pihak lawan tanpa memperhatikan norma dan nilai yang berlaku (Soekanto, 1993:99). Menurut Surbakti (1992: 149) konflik memiliki pengertian benturan, seperti perbedaan pendapat, persaingan, dan pertentangan antara individu dan individu, kelompok dan kelompok, indivudu dan kelompok, dan antara individu atau kelompok dengan pemerintah. Pruitt dan Rubin (2004: 9-10) kemudian memberikan sebuah definisi tentang konflik, yakni bahwa konflik berarti persepsi mengenai perbedaan kepentingan (perceived divergence of interest) atau suatu kepercayaan bahwa aspirasi pihak-pihak yang berkonflik tidak dapat dicapai secara simultan.

Dari beberapa definisi tentang konflik, Liliweri (2005: 250) kemudian menyimpulkan bahwa konflik memiliki unsur sebagai berikut: (1) ada dua pihak atau lebih yang terlibat. Jadi ada interaksi antara mereka yang terlibat; (2) ada tujuan yang dijadikan sasaran konflik, dimana tujuan itulah yang menjadi sumber konflik; (3) ada perbedaan pikiran, perasaan, tindakan di antara pihak yang terlibat untuk mendapatkan atau mencapai tujuan (sasaran); dan (4) ada situasi konflik antara dua pihak yang bertentangan, meliputi situasi antarpribadi, antarkelompok, dan antarorganisasi.

Dalam konteks konflik antara kelompok korban bencana Lumpur Lapindo, maka dapat dijelaskan sebagai berikut: (1) bahwa konflik terjadi dengan melibatkan berbagai kelompok korban bencana Lumpur Lapindo, khususnya 
kelompok GKLL dan Pagarekorlap (Pagarekontrak). Konflik juga melibatkan kelompok Tim-16 dan kelompok Geppres; (2) tujuan dari konflik antar kelompok korban bencana Lumpur Lapindo adalah terletak pada upaya mereka untuk memperoleh ganti rugi atas aset tanah dan rumah yang hancur' (3) konflik antara kelompok korban bencana Lumpur Lapindo dipicu oleh adanya perbedaan (friksi) yakni friksi terkait terjadinya perubahan nama kelompok, friksi dalam perubahan bentuk tuntutan skema proses pembayaran ganti rugi, dan friksi karena terjadinya perubahan strategi; dan (4) bahwa situasi konflik terjadi dalam konteks konflik antar kelompok.

Konflik antar kelompok korban bencana Lumpur Lapindo merupakan bentuk konflik horisontal. Penjelasan tentang konflik horisontal dapat mengacu kepada perspektif teori konflik kontemporer. Perspektif teori konflik kontemporer yang bisa dijadikan dasar acuan dalam penelitian ini adalah perspektif konflik dari Dahrehdorf. Bagi Dahrendorf (Susan, 2010: 55), konflik hanya muncul melalui relasi-relasi sosial dalam sistem. Setiap individu atau kelompok yang tidak terhubung dalam sistem tidak akan mungkin terlibat dalam konflik. Lebih lanjut Dahrendorf menyatakan bahwa unit analisis dalam sosiologi konflik adalah keterpaksaan yang menciptakan organisasiorganisasi sosial bisa bersama sebagai sistem sosial.

Dahrendorf memahami relasi-relasi dalam struktur sosial ditentukan oleh kekuasaan. Esensi kekuasaan yang dimaksudkan oleh Dahrendorf adalah kekuasaan kontrol dan sanksi-sanksi sehingga memungkinkan mereka memiliki kekuasaan memberi berbagai perintah dan mendapatkan apa yang mereka inginkan dari mereka yang tidak memiliki kekuasaan. Jadi dalam pandangan Dahrendorf, konflik kepentingan menjadi fakta tidak terhindarkan dari mereka yang memiliki kekuasaan dan tidak memiliki kekuasaan.

Kekuasaan dalam masyarakat modern dan industrial bisa diterjemahkan sebagai wewenang (authority). Dahrendorf melihat wewenang adalah (1) relasi wewenang, yaitu selalu relasi-relasi antara super dan subordinasi; (2) dimana ada relasirelasi wewenang, kelompok-kelompok superdinasi selalu diharapkan mengontrol perilaku kelompok-kelompok subordinasi melalui permintaan dan perintah serta peringatan dan larangan; (3) berbagai harapan tertanam relatif permanen dalam posisi sosial daripada karakter individual; (4) dengan keberadaan fakta ini, kekuasaan 
superdordinat, mereka selalu melibatkan spesifikasi subjek-subjek perorangan untuk mengontrol danspesifikasi dari ruang sosial yang kontrol mungkin dilakukan; dan (5) wewenang menjadi hubungan terelegitimasi, tanpa protes dengan perintah-perintah otoritatif dapat diberi sanksi, sesungguhnya ini merupakan fungsi sebenarnya dari sistem legal untuk mendukung pemberlakuan wewenang yang memiliki legitimasi.

Menurut Dahrendorf, tatanan sosial dipelihara oleh proses penciptaan hubungan-hubungan wewenang dalam bermacam-macam tipe kelompok terkoordinasi yang ada hingga seluruh lapisan sistem sosial. Kekuasaan dan wewenang adalah sumber langka yang membuat kelompok-kelompok saling bersaing dan berkelahi. Dahrendorf menyebut teorinya ini dengan teori koersi struktur sosial (Susan, 2010: 57).

\section{Kesimpulan}

Korban bencana Lumpur Lapindo membentuk berbagai kelompok untuk menyatukan kekuatan kolektif dalam menuntut hak-hak mereka terutama hak ganti rugi atas aset tanah dan bangunan yang hancur tergenang lumpur. Paling tidak terdapat dua kelompok utama korban bencana Lumpur Lapindo, yakni kelompok Gabungan Korban Lumpur Lapindo (GKLL) dan kelompok Paguyuban Warga Renokenongo Korban Lumpur Lapindo (Pagarekorlap). Konflik antar-kelompok korban bencana Lumpur Lapindo terjadi karena adanya friksi dalam tiga hal, yakni friksi karena terjadinya perubahan nama kelompok, friksi dalam perubahan bentuk tuntutan skema proses pembayaran ganti rugi, dan friksi karena terjadinya perubahan strategi. Sedangkan bentuk konflik antar-kelompok korban bencana Lumpur Lapindo terjadi dalam bentuk: konflik kepentingan antar pemimpin kelompok korban bencana Lumpur Lapindo, konflik strategi aksi antar-kelompok korban bencana Lumpur Lapindo, dan konflik tuntutan mekanisme pembayaran ganti rugi atas aset tanah dan bangunan milik korban bencana Lumpur Lapindo.

Konflik antar-kelompok korban bencana Lumpur Lapindo menyebabkan terjadinya perpecahan di antara korban bencana Lumpur Lapindo sehingga kekuatan kolektif kelompok menjadi tidak efektif dalam memperjuangkan tuntutan hak ganti rugi kepada pihak pemerintan dan korporasi. 


\section{Ucapan Terima Kasih}

Terimakasih disampaikan kepada Dekan Fakultas Ilmu Sosial dan Ilmu Politik, Universitas Muhammadiyah Malang, yang telah membiayai penelitian ini melalui dana penelitian blockgrant tahun 2016.

\section{Daftar Rujukan}

Babbie, E. (2008). The Basics of Social Research. Belmont, USA: Thomson Wadsworth.

Denzin, N. K.., \& Lincoln, Y. S. (2009). Handbook of Qualitative Research (terj.). Yogyakarta: PustakaPelajar.

Deutsh, M., C., P. T. \& Marcus, E. C. (2006). The Handbook of Conflict Resolution: Theory and Practice. San Fransisco: Jossey-Bass.

Haralambos, M., \& Holborn, M. (1994). Sociology: Themes and Perspectives. London: Collins Eduactonal.

Johnson, D. W. \& Johnson, F. P. (2000). Joining Together: Group Theory and Group Skills. Boston: Allyn and Bacon.

Klandermans, B. \& Stagenborg, S. (eds.). (2002). Methods of Social Movements Research. Minneapolis: University of Minnesota Press.

Kartini, K. (1983). Mental Hygiene (Kesehatan Mental). Bandung: Alumni.

Liliweri, A. (2005). Prasangka dan Konflik: Komunikasi Lintas Budaya Masyarakat Multikultur. Yogyakarta: LKiS.

Maliki, Z. (2003). Narasi Agung Tiga Teori Sosial Hegemonik. Surabaya: Penerbit Lembaga Pengkajian Agama dan Masyarakat (LPAM).

Marvasti, A. B. (2004). Qualitative Research in Sociology: An Introduction. New Delhi: Sage Publications.

Neuman, W. L. (2007). Basics of Social Research: Qualitative and Quantitative Appoaches. Boston: Pearson Education, Inc.

Pruitt, D. G. \& Rubin, J. Z. (2004). Teori Konflik Sosial. Yogyakarta: Pustaka Pelajar.

Raho, B. (2007). Teori Sosiologi Modern. Jakarta: Prestasi Pustaka Publisher.

Ritzer, G., \& Goodman, D. J. (2004). Teori Sosiologi: Dari Teori Sosiologi Klasik sampai Perkembangan Mutakhir Teori Sosial Postmodern. Yogyakarta: KreasiWacana. Salim, A. (peny.). (2001). Teoridan Paradigma Penelitan Sosial: Pemikiran Norman K. Denæin \& Egon Guba, dan penerapannya. Yogyakarta: Tiara Wacana. 
Soekanto, S. (1986). Sosiologi Suatu Pengantar. Jakarta: Rajawali Pers.

Surbakti, R. (1992). Memahami Ilmu Politik. Jakarta: Grasindo.

Susan, N. (2010). Pengantar Sosiologi Konflik dan Isu-Isu Konflik Kontemporer. Jakarta: Kencana Prenada Media Group.

Wirawan, I. B. (2012). Teori-Teori Sosial dalam Tiga Paradigma: Fakta Sosial, Definisi Sosial, \& Perilaku Sosial. Jakarta: Kencana Prenada Media Group.

Yin, R. K. (2011). Qualitative Research from Start to Finish. New York: The Guilford Press. 